\title{
Lysophospholipid (S1P) receptors (version 2020.5) in the IUPHAR/BPS Guide to Pharmacology Database
}

\author{
Victoria Blaho ${ }^{1}$, Jerold Chun ${ }^{1}$, Danielle Jones ${ }^{1}$, Deepa Jonnalagadda ${ }^{1}$, Yasuyuki Kihara ${ }^{1}$ and Valerie Tan ${ }^{1}$ \\ 1. Sanford Burnham Prebys Medical Discovery Institute, USA
}

\begin{abstract}
Sphingosine 1-phosphate (S1P) receptors (nomenclature as agreed by the NC-IUPHAR Subcommittee on Lysophospholipid receptors [86]) are activated by the endogenous lipidsphingosine 1-phosphate (S1P). Originally cloned as orphan members of the endothelial differentiation gene (edg) family, current gene names have been designated as $\mathrm{S}_{1} \mathrm{P}_{1} \mathrm{R}$ through $\mathrm{S}_{1} \mathrm{P}_{5} \mathrm{R}[66,16,109]$. S1PRs, particularly $\mathrm{S}_{1} \mathrm{P}_{1}$, are expressed throughout all mammalian organ systems. Ligand delivery occurs via two known carriers (or "chaperones"): albumin and HDL-bound apolipoprotein M (ApoM), the latter of which elicits biased agonist signaling by S1 $\mathrm{P}_{1}$ in multiple cell types $[18,48]$. The five S1PRs, two chaperones, and active cellular metabolism have complicated analyses of receptor ligand binding in native systems. Signaling pathways and physiological roles have been characterized through radioligand binding in heterologous expression systems, targeted deletion of the different S1PRs, and most recently, mouse models that report in vivo S1P1R activation [91, 93]. A crystal structure of an $\mathrm{S}_{1} \mathrm{P}_{1}$-T4 fusion protein confirmed aspects of ligand binding, specificity, and receptor activation determined previously through biochemical and genetic studies [62,17]. fingolimod (FTY720), the first drug to target any of the lysophospholipid receptors, binds to four of the five S1PRs, and was the first oral therapy for multiple sclerosis )MS) [32]. siponimod and ozanimod that target $\mathrm{S}_{1} \mathrm{P}_{1}$ and $\mathrm{S}_{1} \mathrm{P}_{5}$ are also FDA approved for the treatment of various MS forms [16, 109]. The mechanisms of action of fingolimod and other S1PR modulating drugs in development include binding S1PRs in multiple organ systems, e.g., immune and nervous systems, although the precise nature of their receptor interactions requires clarification $[126,34,56,57]$.
\end{abstract}

\section{Contents}

This is a citation summary for Lysophospholipid (S1P) receptors in the Guide to Pharmacology database (GtoPdb). It exists purely as an adjunct to the database to facilitate the recognition of citations to and from the database by citation analyzers. Readers will almost certainly want to visit the relevant sections of the database which are given here under database links.

GtoPdb is an expert-driven guide to pharmacological targets and the substances that act on them. GtoPdb is a reference work which is most usefully represented as an on-line database. As in any publication this work should be appropriately cited, and the papers it cites should also be recognized. This document provides a citation for the relevant parts of the database, and also provides a reference list for the research cited by those parts.

Please note that the database version for the citations given in GtoPdb are to the most recent preceding version in which the family or its subfamilies and targets were substantially changed. The links below are to the current version. If you need to consult the cited version, rather than the most recent version, please contact the GtoPdb curators.

\section{Database links}

Lysophospholipid (S1P) receptors

https://www.guidetopharmacology.org/GRAC/FamilyDisplayForward?familyld=135 Introduction to Lysophospholipid (S1P) receptors

https://www.guidetopharmacology.org/GRAC/FamilyIntroductionForward?familyld=135

Receptors

$\mathrm{S} 1 \mathrm{P}_{1}$ receptor

https://www.guidetopharmacology.org/GRAC/ObjectDisplayForward?objectld=275

$\mathrm{S}_{1} \mathrm{P}_{2}$ receptor

https://www.guidetopharmacology.org/GRAC/ObjectDisplayForward?objectld=276 
$\mathrm{S}_{1} \mathrm{P}_{3}$ receptor

https://www.guidetopharmacology.org/GRAC/ObjectDisplayForward?objectld=277

$\mathrm{S}_{1} \mathrm{P}_{4}$ receptor

https://www.guidetopharmacology.org/GRAC/ObjectDisplayForward?objectld=278

$\mathrm{S}_{1} \mathrm{P}_{5}$ receptor

https://www.guidetopharmacology.org/GRAC/ObjectDisplayForward?objectld=279

\section{References}

1. Albert R, Hinterding K, Brinkmann V, Guerini D, Müller-Hartwieg C, Knecht $H$, Simeon C, Streiff M, Wagner T and Welzenbach K et al.. (2005) Novel immunomodulator FTY720 is phosphorylated in rats and humans to form a single stereoisomer. Identification, chemical proof, and biological characterization of the biologically active species and its enantiomer. J. Med. Chem. 48: 5373-7 [PMID:16078855]

2. Allende ML, Bektas M, Lee BG, Bonifacino E, Kang J, Tuymetova G, Chen W, Saba JD and Proia RL. (2011) Sphingosine-1-phosphate lyase deficiency produces a pro-inflammatory response while impairing neutrophil trafficking. J. Biol. Chem. 286: 7348-58 [PMID:21173151]

3. Allende ML, Dreier JL, Mandala S and Proia RL. (2004) Expression of the sphingosine 1-phosphate receptor, S1P1, on T-cells controls thymic emigration. J. Biol. Chem. 279: 15396-401 [PMID:14732704]

4. Allende ML, Tuymetova G, Lee BG, Bonifacino E, Wu YP and Proia RL. (2010) S1P1 receptor directs the release of immature B cells from bone marrow into blood. J. Exp. Med. 207: 1113-24 [PMID:20404103]

5. Allende ML, Yamashita T and Proia RL. (2003) G-protein-coupled receptor S1P1 acts within endothelial cells to regulate vascular maturation. Blood 102: 3665-7 [PMID:12869509]

6. Allende ML, Zhou D, Kalkofen DN, Benhamed S, Tuymetova G, Borowski C, Bendelac A and Proia RL. (2008) S1P1 receptor expression regulates emergence of NKT cells in peripheral tissues. FASEB J. 22: 307-15 [PMID:17785606]

7. An S, Zheng Y and Bleu T. (2000) Sphingosine 1-phosphate-induced cell proliferation, survival, and related signaling events mediated by G protein-coupled receptors Edg3 and Edg5. J. Biol. Chem. 275: 288-96 [PMID:10617617]

8. Ancellin N and Hla T. (1999) Differential pharmacological properties and signal transduction of the sphingosine 1-phosphate receptors EDG-1, EDG-3, and EDG-5. J. Biol. Chem. 274: 18997-9002 [PMID:10383399]

9. Andrieu G, Ledoux A, Branka S, Bocquet M, Gilhodes J, Walzer T, Kasahara K, Inagaki M, Sabbadini RA and Cuvillier O et al.. (2017) Sphingosine 1-phosphate signaling through its receptor S1P promotes chromosome segregation and mitotic progression. Sci Signal 10: [PMID:28351953]

10. Arikawa K, Takuwa N, Yamaguchi H, Sugimoto N, Kitayama J, Nagawa H, Takehara K and Takuwa Y. (2003) Ligand-dependent inhibition of B16 melanoma cell migration and invasion via endogenous S1P2 G protein-coupled receptor. Requirement of inhibition of cellular RAC activity. J. Biol. Chem. 278: 32841-51 [PMID:12810709]

11. Awojoodu AO, Ogle ME, Sefcik LS, Bowers DT, Martin K, Brayman KL, Lynch KR, Peirce-Cottler SM and Botchwey E. (2013) Sphingosine 1-phosphate receptor 3 regulates recruitment of anti-inflammatory monocytes to microvessels during implant arteriogenesis. Proc. Natl. Acad. Sci. U.S.A. 110: 13785-90 [PMID:23918395]

12. Baeyens AAL and Schwab SR. (2020) Finding a Way Out: S1P Signaling and Immune Cell Migration. Annu Rev Immuno/38: 759-784 [PMID:32340572]

13. Bajwa A, Huang L, Ye H, Dondeti K, Song S, Rosin DL, Lynch KR, Lobo PI, Li L and Okusa MD. (2012) Dendritic cell sphingosine 1-phosphate receptor-3 regulates Th1-Th2 polarity in kidney ischemiareperfusion injury. J. Immunol. 189: 2584-96 [PMID:22855711]

14. Banno Y, Takuwa Y, Akao Y, Okamoto H, Osawa Y, Naganawa T, Nakashima S, Suh PG and Nozawa Y. (2001) Involvement of phospholipase D in sphingosine 1-phosphate-induced activation of phosphatidylinositol 3-kinase and Akt in Chinese hamster ovary cells overexpressing EDG3. J. Biol. Chem. 276: 35622-8 [PMID:11468290]

15. Baudhuin LM, Jiang Y, Zaslavsky A, Ishii I, Chun J and Xu Y. (2004) S1P3-mediated Akt activation and cross-talk with platelet-derived growth factor receptor (PDGFR). FASEB J. 18: 341-3 [PMID:14657000]

16. Blaho VA. (2020) Druggable Sphingolipid Pathways: Experimental Models and Clinical Opportunities. Adv Exp Med Biol 1274: 101-135 [PMID:32894509]

17. Blaho VA and Chun J. (2018) 'Crystal' Clear? Lysophospholipid Receptor Structure Insights and Controversies. Trends Pharmacol. Sci. 39: 953-966 [PMID:30343728]

18. Blaho VA, Galvani S, Engelbrecht E, Liu C, Swendeman SL, Kono M, Proia RL, Steinman L, Han MH and Hla T. (2015) HDL-bound sphingosine-1-phosphate restrains lymphopoiesis and neuroinflammation. Nature 523: 342-6 [PMID:26053123]

19. Bolli MH, Abele S, Binkert C, Bravo R, Buchmann S, Bur D, Gatfield J, Hess P, Kohl C and Mangold Cet al.. (2010) 2-imino-thiazolidin-4-one derivatives as potent, orally active S1P1 receptor agonists.J. Med. Chem. 53: 4198-211 [PMID:20446681]

20. Brinkmann V, Davis MD, Heise CE, Albert R, Cottens S, Hof R, Bruns C, Prieschl E, Baumruker T and Hiestand P et al.. (2002) The immune modulator FTY720 targets sphingosine 1-phosphate receptors.J. Biol. Chem. 277: 21453-7 [PMID:11967257]

21. Brizuela L, Rábano M, Gangoiti P, Narbona N, Macarulla JM, Trueba M and Gómez-Muñoz A. (2007) 
Sphingosine-1-phosphate stimulates aldosterone secretion through a mechanism involving the PI3K/PKB and MEK/ERK 1/2 pathways. J. Lipid Res. 48: 2264-74 [PMID:17609523]

22. Brizuela L, Rábano M, Peña A, Gangoiti P, Macarulla JM, Trueba M and Gómez-Muñoz A. (2006) Sphingosine 1-phosphate: a novel stimulator of aldosterone secretion. J. Lipid Res. 47: 1238-49 [PMID:16554657]

23. Buvinic S, Briones R and Huidobro-Toro JP. (2002) P2Y(1) and P2Y(2) receptors are coupled to the NO/cGMP pathway to vasodilate the rat arterial mesenteric bed. Br. J. Pharmacol. 136: 847-56 [PMID:12110609]

24. Buzard DJ, Kim SH, Lopez L, Kawasaki A, Zhu X, Moody J, Thoresen L, Calderon I, Ullman B and Han S et al.. (2014) Discovery of APD334: Design of a Clinical Stage Functional Antagonist of the Sphingosine-1phosphate-1 Receptor. ACS Med Chem Lett 5: 1313-7 [PMID:25516790]

25. Cahalan SM, Gonzalez-Cabrera PJ, Sarkisyan G, Nguyen N, Schaeffer MT, Huang L, Yeager A, Clemons

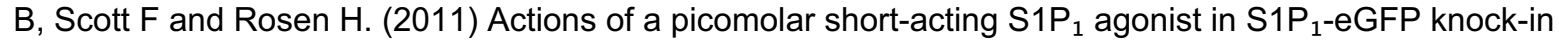
mice. Nat. Chem. Biol. 7: 254-6 [PMID:21445057]

26. Candelore MR, Wright MJ, Tota LM, Milligan J, Shei GJ, Bergstrom JD and Mandala SM. (2002) Phytosphingosine 1-phosphate: a high affinity ligand for the S1P(4)/Edg-6 receptor. Biochem. Biophys. Res. Commun. 297: 600-6 [PMID:12270137]

27. Cattoretti G, Mandelbaum J, Lee N, Chaves AH, Mahler AM, Chadburn A, Dalla-Favera R, Pasqualucci L and MacLennan AJ. (2009) Targeted disruption of the S1P2 sphingosine 1-phosphate receptor gene leads to diffuse large B-cell lymphoma formation. Cancer Res. 69: 8686-92 [PMID:19903857]

28. Cencetti F, Bernacchioni C, Tonelli F, Roberts E, Donati C and Bruni P. (2013) TGF $\beta 1$ evokes myoblast apoptotic response via a novel signaling pathway involving S1P4 transactivation upstream of Rho-kinase2 activation. FASEB J. 27: 4532-46 [PMID:23913862]

29. CHARGE Consortium Hematology Working Group. (2016) Meta-analysis of rare and common exome chip variants identifies S1PR4 and other loci influencing blood cell traits. Nat Genet 48: 867-76 [PMID:27399967]

30. Choi JW, Gardell SE, Herr DR, Rivera R, Lee CW, Noguchi K, Teo ST, Yung YC, Lu M and Kennedy Get al.. (2011) FTY720 (fingolimod) efficacy in an animal model of multiple sclerosis requires astrocyte sphingosine 1-phosphate receptor 1 (S1P1) modulation. Proc. Natl. Acad. Sci. U.S.A. 108: 751-6 [PMID:21177428]

31. Chun J, Hla T, Lynch KR, Spiegel S and Moolenaar WH. (2010) International Union of Basic and Clinical Pharmacology. LXXVIII. Lysophospholipid receptor nomenclature. Pharmacol. Rev. 62: 579-87 [PMID:21079037]

32. Chun J, Kihara Y, Jonnalagadda D and Blaho VA. (2019) Fingolimod: Lessons Learned and New Opportunities for Treating Multiple Sclerosis and Other Disorders. Annu. Rev. Pharmacol. Toxicol. 59: 149170 [PMID:30625282]

33. Cinamon G, Zachariah MA, Lam OM, Foss Jr FW and Cyster JG. (2008) Follicular shuttling of marginal zone B cells facilitates antigen transport. Nat. Immunol. 9: 54-62 [PMID:18037889]

34. Cohen JA and Chun J. (2011) Mechanisms of fingolimod's efficacy and adverse effects in multiple sclerosis. Ann. Neurol. 69: $759-77$ [PMID:21520239]

35. Contos JJ, Ye X, Sah VP and Chun J. (2002) Tandem genomic arrangement of a G protein (Gna15) and G protein-coupled receptor (s1p(4)/lp(C1)/Edg6) gene. FEBS Lett. 531: 99-102 [PMID:12401211]

36. Davis MD, Clemens JJ, Macdonald TL and Lynch KR. (2005) Sphingosine 1-phosphate analogs as receptor antagonists. J. Biol. Chem. 280: 9833-41 [PMID:15590668]

37. Debien E, Mayol K, Biajoux V, Daussy C, De Aguero MG, Taillardet M, Dagany N, Brinza L, Henry T and Dubois B et al.. (2013) S1PR5 is pivotal for the homeostasis of patrolling monocytes. Eur. J. Immunol. 43: 1667-75 [PMID:23519784]

38. Demont EH, Bailey JM, Bit RA, Brown JA, Campbell CA, Deeks N, Dowell SJ, Eldred C, Gaskin P and Gray JR et al.. (2016) Discovery of Tetrahydropyrazolopyridine as Sphingosine 1-Phosphate Receptor 3 (S1P3)-Sparing S1P1 Agonists Active at Low Oral Doses. J. Med. Chem. 59: 1003-20 [PMID:26751273]

39. Deng Q, Clemas JA, Chrebet G, Fischer P, Hale JJ, Li Z, Mills SG, Bergstrom J, Mandala S and Mosley R et al.. (2007) Identification of Leu276 of the S1P1 receptor and Phe263 of the S1P3 receptor in interaction with receptor specific agonists by molecular modeling, site-directed mutagenesis, and affinity studies. Mol. Pharmacol. 71: 724-35 [PMID:17170199]

40. Di Pardo A, Castaldo S, Amico E, Pepe G, Marracino F, Capocci L, Giovannelli A, Madonna M, van Bergeijk J and Buttari F et al.. (2018) Stimulation of S1PR5 with A-971432, a selective agonist, preserves blood-brain barrier integrity and exerts therapeutic effect in an animal model of Huntington's disease. Hum. Mol. Genet. 27: 2490-2501 [PMID:29688337]

41. Dillmann C, Mora J, Olesch C, Brüne B and Weigert A. (2015) S1PR4 is required for plasmacytoid dendritic cell differentiation. Biol Chem 396: 775-82 [PMID:25720060]

42. Donovan EE, Pelanda R and Torres RM. (2010) S1P3 confers differential S1P-induced migration by autoreactive and non-autoreactive immature $B$ cells and is required for normal B-cell development. Eur. J. Immunol. 40: 688-98 [PMID:20039302]

43. Drouillard A, Neyra A, Mathieu AL, Marçais A, Wencker M, Marvel J, Belot A and Walzer T. (2018) Human Naive and Memory T Cells Display Opposite Migratory Responses to Sphingosine-1 Phosphate. $J$ Immunol 200: 551-557 [PMID:29237776]

44. Faroudi M, Hons M, Zachacz A, Dumont C, Lyck R, Stein JV and Tybulewicz VL. (2010) Critical roles for Rac GTPases in T-cell migration to and within lymph nodes. Blood 116: 5536-47 [PMID:20870900] 
45. Fettel J, Kühn B, Guillen NA, Sürün D, Peters M, Bauer R, Angioni C, Geisslinger G, Schnütgen F and Meyer Zu Heringdorf D et al.. (2019) Sphingosine-1-phosphate (S1P) induces potent anti-inflammatory effects in vitro and in vivo by S1P receptor 4-mediated suppression of 5-lipoxygenase activity. FASEB J 33: 1711-1726 [PMID:30188757]

46. Forrest M, Sun SY, Hajdu R, Bergstrom J, Card D, Doherty G, Hale J, Keohane C, Meyers C and Milligan J et al.. (2004) Immune cell regulation and cardiovascular effects of sphingosine 1-phosphate receptor agonists in rodents are mediated via distinct receptor subtypes. J. Pharmacol. Exp. Ther. 309: 758-68 [PMID:14747617]

47. Foss FW, Snyder AH, Davis MD, Rouse M, Okusa MD, Lynch KR and Macdonald TL. (2007) Synthesis and biological evaluation of gamma-aminophosphonates as potent, subtype-selective sphingosine 1phosphate receptor agonists and antagonists. Bioorg. Med. Chem. 15: 663-77 [PMID:17113298]

48. Galvani S, Sanson M, Blaho VA, Swendeman SL, Obinata H, Conger H, Dahlbäck B, Kono M, Proia RL and Smith JD et al.. (2015) HDL-bound sphingosine 1-phosphate acts as a biased agonist for the endothelial cell receptor S1P1 to limit vascular inflammation. Sci Signal 8: ra79 [PMID:26268607]

49. Gates E. (1998) A complement to care. Nurs Times 94: 55-7 [PMID:9735753]

50. Gergely P, Nuesslein-Hildesheim B, Guerini D, Brinkmann V, Traebert M, Bruns C, Pan S, Gray NS, Hinterding $\mathrm{K}$ and Cooke NG et al.. (2012) The selective sphingosine 1-phosphate receptor modulator BAF312 redirects lymphocyte distribution and has species-specific effects on heart rate. Br. J. Pharmacol. 167: 1035-47 [PMID:22646698]

51. Glaenzel U, Jin Y, Nufer R, Li W, Schroer K, Adam-Stitah S, Peter van Marle S, Legangneux E, Borell H and James AD et al.. (2018) Metabolism and Disposition of Siponimod, a Novel Selective S1P $/ \mathrm{S}_{1} \mathrm{P}_{5}$ Agonist, in Healthy Volunteers and In Vitro Identification of Human Cytochrome P450 Enzymes Involved in Its Oxidative Metabolism. Drug Metab. Dispos. 46: 1001-1013 [PMID:29735753]

52. Golfier S, Kondo S, Schulze T, Takeuchi T, Vassileva G, Achtman AH, Gräler MH, Abbondanzo SJ, Wiekowski M and Kremmer E et al.. (2010) Shaping of terminal megakaryocyte differentiation and proplatelet development by sphingosine-1-phosphate receptor S1P4. FASEB J. 24: 4701-10 [PMID:20686109]

53. Gonda K, Okamoto H, Takuwa N, Yatomi Y, Okazaki H, Sakurai T, Kimura S, Sillard R, Harii K and Takuwa Y. (1999) The novel sphingosine 1-phosphate receptor AGR16 is coupled via pertussis toxinsensitive and -insensitive G-proteins to multiple signalling pathways. Biochem. J. 337 ( Pt 1): 67-75 [PMID:9854026]

54. Gonzalez-Cabrera PJ, Jo E, Sanna MG, Brown S, Leaf N, Marsolais D, Schaeffer MT, Chapman J, Cameron M and Guerrero M et al.. (2008) Full pharmacological efficacy of a novel S1P1 agonist that does not require S1P-like headgroup interactions. Mol. Pharmacol. 74: 1308-18 [PMID:18708635]

55. Green JA, Suzuki K, Cho B, Willison LD, Palmer D, Allen CD, Schmidt TH, Xu Y, Proia RL and Coughlin SR et al.. (2011) The sphingosine 1-phosphate receptor $\mathrm{S}_{1} \mathrm{P}_{2}$ maintains the homeostasis of germinal center B cells and promotes niche confinement. Nat Immunol 12: 672-80 [PMID:21642988]

56. Groves A, Kihara Y and Chun J. (2013) Fingolimod: direct CNS effects of sphingosine 1-phosphate (S1P) receptor modulation and implications in multiple sclerosis therapy. J. Neurol. Sci. 328: 9-18 [PMID:23518370]

57. Groves A, Kihara Y, Jonnalagadda D, Rivera R, Kennedy G, Mayford M and Chun J. (2018) A Functionally Defined In Vivo Astrocyte Population Identified by c-Fos Activation in a Mouse Model of Multiple Sclerosis Modulated by S1P Signaling: Immediate-Early Astrocytes (ieAstrocytes). eNeuro 5: [PMID:30255127]

58. Gräler MH, Bernhardt G and Lipp M. (1998) EDG6, a novel G-protein-coupled receptor related to receptors for bioactive lysophospholipids, is specifically expressed in lymphoid tissue. Genomics 53: 164-9 [PMID:9790765]

59. Gräler MH, Grosse R, Kusch A, Kremmer E, Gudermann T and Lipp M. (2003) The sphingosine 1phosphate receptor S1P4 regulates cell shape and motility via coupling to Gi and G12/13. J. Cell. Biochem. 89: 507-19 [PMID:12761884]

60. Guerrero M, Urbano M, Velaparthi S, Zhao J, Schaeffer MT, Brown S, Rosen H and Roberts E. (2011) Discovery, design and synthesis of the first reported potent and selective sphingosine-1-phosphate 4 (S1P4) receptor antagonists. Bioorg. Med. Chem. Lett. 21: 3632-6 [PMID:21570287]

61. Hale JJ, Lynch CL, Neway W, Mills SG, Hajdu R, Keohane CA, Rosenbach MJ, Milligan JA, Shei GJ and Parent SA et al.. (2004) A rational utilization of high-throughput screening affords selective, orally bioavailable 1-benzyl-3-carboxyazetidine sphingosine-1-phosphate-1 receptor agonists. J. Med. Chem. 47: 6662-5 [PMID:15615513]

62. Hanson MA, Roth CB, Jo E, Griffith MT, Scott FL, Reinhart G, Desale H, Clemons B, Cahalan SM and Schuerer SC et al.. (2012) Crystal structure of a lipid G protein-coupled receptor.Science 335: 851-5 [PMID:22344443]

63. Herr DR, Grillet N, Schwander M, Rivera R, Müller U and Chun J. (2007) Sphingosine 1-phosphate (S1P) signaling is required for maintenance of hair cells mainly via activation of S1P2. J. Neurosci. 27: 1474-8 [PMID:17287522]

64. Herr DR, Lee CW, Wang W, Ware A, Rivera R and Chun J. (2013) Sphingosine 1-phosphate receptors are essential mediators of eyelid closure during embryonic development. J. Biol. Chem. 288: 29882-9 [PMID:24003216]

65. Hill RZ, Morita T, Brem RB and Bautista DM. (2018) S1PR3 Mediates Itch and Pain via Distinct TRP Channel-Dependent Pathways. J. Neurosci. 38: 7833-7843 [PMID:30082422] 
66. Hla T and Maciag T. (1990) An abundant transcript induced in differentiating human endothelial cells encodes a polypeptide with structural similarities to G-protein-coupled receptors. J. Biol. Chem. 265: 930813 [PMID:2160972]

67. Hobson AD, Harris CM, van der Kam EL, Turner SC, Abibi A, Aguirre AL, Bousquet P, Kebede T, Konopacki DB and Gintant G et al.. (2015) Discovery of A-971432, An Orally Bioavailable Selective Sphingosine-1-Phosphate Receptor 5 (S1P5) Agonist for the Potential Treatment of Neurodegenerative Disorders. J. Med. Chem. 58: 9154-70 [PMID:26509640]

68. Hur W, Rosen H and Gray NS. (2017) A benzo[b]thiophene-based selective type 4 S1P receptor agonist. Bioorg. Med. Chem. Lett. 27: 1-5 [PMID:27894870]

69. Högenauer K, Billich A, Pally C, Streiff M, Wagner T, Welzenbach K and Nussbaumer P. (2008) Phosphorylation by sphingosine kinase 2 is essential for in vivo potency of FTY720 analogues. ChemMedChem 3: 1027-9 [PMID:18383466]

70. Idzko M, Hammad H, van Nimwegen M, Kool M, Müller T, Soullié T, Willart MA, Hijdra D, Hoogsteden HC and Lambrecht BN. (2006) Local application of FTY720 to the lung abrogates experimental asthma by altering dendritic cell function. J. Clin. Invest. 116: 2935-44 [PMID:17080194]

71. Idzko M, Panther E, Corinti S, Morelli A, Ferrari D, Herouy Y, Dichmann S, Mockenhaupt M, GebickeHaerter P and Di Virgilio F et al.. (2002) Sphingosine 1-phosphate induces chemotaxis of immature and modulates cytokine-release in mature human dendritic cells for emergence of Th2 immune responses. FASEB J. 16: 625-7 [PMID:11919175]

72. Ikeda $\mathrm{H}$, Satoh $\mathrm{H}$, Yanase $\mathrm{M}$, Inoue $\mathrm{Y}$, Tomiya $\mathrm{T}$, Arai M, Tejima K, Nagashima K, Maekawa H and Yahagi $\mathrm{N}$ et al.. (2003) Antiproliferative property of sphingosine 1-phosphate in rat hepatocytes involves activation of Rho via Edg-5. Gastroenterology 124: 459-69 [PMID:12557151]

73. Im DS, Clemens J, Macdonald TL and Lynch KR. (2001) Characterization of the human and mouse sphingosine 1-phosphate receptor, S1P5 (Edg-8): structure-activity relationship of sphingosine1phosphate receptors. Biochemistry 40: 14053-60 [PMID:11705398]

74. Im DS, Heise CE, Ancellin N, O'Dowd BF, Shei GJ, Heavens RP, Rigby MR, Hla T, Mandala S and McAllister G et al.. (2000) Characterization of a novel sphingosine 1-phosphate receptor, Edg-8.J. Biol. Chem. 275: 14281-6 [PMID:10799507]

75. Inoki I, Takuwa N, Sugimoto N, Yoshioka K, Takata S, Kaneko S and Takuwa Y. (2006) Negative regulation of endothelial morphogenesis and angiogenesis by S1P2 receptor. Biochem. Biophys. Res. Commun. 346: 293-300 [PMID:16756949]

76. Ishii I, Friedman B, Ye X, Kawamura S, McGiffert C, Contos JJ, Kingsbury MA, Zhang G, Brown JH and Chun J. (2001) Selective loss of sphingosine 1-phosphate signaling with no obvious phenotypic abnormality in mice lacking its G protein-coupled receptor, LP(B3)/EDG-3. J. Biol. Chem. 276: 33697-704 [PMID:11443127]

77. Ishii I, Ye X, Friedman B, Kawamura S, Contos JJ, Kingsbury MA, Yang AH, Zhang G, Brown JH and Chun J. (2002) Marked perinatal lethality and cellular signaling deficits in mice null for the two sphingosine 1-phosphate (S1P) receptors, S1P(2)/LP(B2)/EDG-5 and S1P(3)/LP(B3)/EDG-3. J. Biol. Chem. 277: 25152-9 [PMID:12006579]

78. Jaillard C, Harrison S, Stankoff B, Aigrot MS, Calver AR, Duddy G, Walsh FS, Pangalos MN, Arimura N and Kaibuchi K et al.. (2005) Edg8/S1P5: an oligodendroglial receptor with dual function on process retraction and cell survival. J. Neurosci. 25: 1459-69 [PMID:15703400]

79. Jenne CN, Enders A, Rivera R, Watson SR, Bankovich AJ, Pereira JP, Xu Y, Roots CM, Beilke JN and Banerjee A et al.. (2009) T-bet-dependent S1P5 expression in NK cells promotes egress from lymph nodes and bone marrow. J. Exp. Med. 206: 2469-81 [PMID:19808259]

80. Jiang LI, Collins J, Davis R, Lin KM, DeCamp D, Roach T, Hsueh R, Rebres RA, Ross EM and Taussig R et al.. (2007) Use of a cAMP BRET sensor to characterize a novel regulation of cAMP by the sphingosine 1-phosphate/G13 pathway. J. Biol. Chem. 282: 10576-84 [PMID:17283075]

81. Jo E, Bhhatarai B, Repetto E, Guerrero M, Riley S, Brown SJ, Kohno Y, Roberts E, Schürer SC and Rosen H. (2012) Novel selective allosteric and bitopic ligands for the S1P(3) receptor. ACS Chem. Biol. 7: 1975-83 [PMID:22971058]

82. Jongsma M, Hendriks-Balk MC, Michel MC, Peters SL and Alewijnse AE. (2006) BML-241 fails to display selective antagonism at the sphingosine-1-phosphate receptor, S1P(3). Br J Pharmacol 149: 277-82 [PMID:16940990]

83. Kabashima K, Haynes NM, Xu Y, Nutt SL, Allende ML, Proia RL and Cyster JG. (2006) Plasma cell S1P1 expression determines secondary lymphoid organ retention versus bone marrow tropism. J. Exp. Med. 203: 2683-90 [PMID:17101733]

84. Kempf A, Tews B, Arzt ME, Weinmann O, Obermair FJ, Pernet V, Zagrebelsky M, Delekate A, lobbi C and Zemmar A et al.. (2014) The Sphingolipid Receptor S1PR2 Is a Receptor for Nogo-A Repressing Synaptic Plasticity. PLoS Biol. 12: e1001763 [PMID:24453941]

85. Kennedy PC, Zhu R, Huang T, Tomsig JL, Mathews TP, David M, Peyruchaud O, Macdonald TL and Lynch KR. (2011) Characterization of a sphingosine 1-phosphate receptor antagonist prodrug. $J$. Pharmacol. Exp. Ther. 338: 879-89 [PMID:21632869]

86. Kihara Y, Maceyka M, Spiegel S and Chun J. (2014) Lysophospholipid receptor nomenclature review: IUPHAR Review 8. Br. J. Pharmacol. 171: 3575-94 [PMID:24602016]

87. Kleinwort A, Lührs F, Heidecke CD, Lipp M and Schulze T. (2018) S1P Signalling Differentially Affects Migration of Peritoneal B Cell Populations In Vitro and Influences the Production of Intestinal IgA In Vivo. Int J Mol Sci 19: [PMID:29382132] 
88. Kohno T, Matsuyuki H, Inagaki Y and Igarashi Y. (2003) Sphingosine 1-phosphate promotes cell migration through the activation of Cdc42 in Edg-6/S1P4-expressing cells. Genes Cells 8: 685-97 [PMID:12875654]

89. Kon J, Sato K, Watanabe T, Tomura H, Kuwabara A, Kimura T, Tamama K, Ishizuka T, Murata N and Kanda T et al.. (1999) Comparison of intrinsic activities of the putative sphingosine 1-phosphate receptor subtypes to regulate several signaling pathways in their cDNA-transfected Chinese hamster ovary cells. $J$. Biol. Chem. 274: 23940-7 [PMID:10446161]

90. Kono M, Belyantseva IA, Skoura A, Frolenkov GI, Starost MF, Dreier JL, Lidington D, Bolz SS, Friedman TB and Hla T et al.. (2007) Deafness and stria vascularis defects in S1P2 receptor-null mice.J. Biol. Chem. 282: 10690-6 [PMID:17284444]

91. Kono M, Conlon EG, Lux SY, Yanagida K, Hla T and Proia RL. (2017) Bioluminescence imaging of G protein-coupled receptor activation in living mice. Nat Commun 8: 1163 [PMID:29079828]

92. Kono M, Mi Y, Liu Y, Sasaki T, Allende ML, Wu YP, Yamashita T and Proia RL. (2004) The sphingosine-1phosphate receptors S1P1, S1P2, and S1P3 function coordinately during embryonic angiogenesis. J. Biol. Chem. 279: 29367-73 [PMID:15138255]

93. Kono M, Tucker AE, Tran J, Bergner JB, Turner EM and Proia RL. (2014) Sphingosine-1-phosphate receptor 1 reporter mice reveal receptor activation sites in vivo. J. Clin. Invest. 124: 2076-86 [PMID:24667638]

94. Kulinski JM, Muñoz-Cano R and Olivera A. (2016) Sphingosine-1-phosphate and other lipid mediators generated by mast cells as critical players in allergy and mast cell function. Eur. J. Pharmacol. 778: 56-67 [PMID:25941085]

95. Kusumi K, Shinozaki K, Yamaura Y, Hashimoto A, Kurata H, Naganawa A, Otsuki K, Matsushita T, Sekiguchi T and Kakuuchi A et al.. (2016) Discovery of novel S1P2 antagonists, part 3: Improving the oral bioavailability of a series of 1,3-bis(aryloxy)benzene derivatives. Bioorg. Med. Chem. Lett. 26: 1209-13 [PMID:26794040]

96. Li Z, Chen W, Hale JJ, Lynch CL, Mills SG, Hajdu R, Keohane CA, Rosenbach MJ, Milligan JA and Shei GJ et al.. (2005) Discovery of potent 3,5-diphenyl-1,2,4-oxadiazole sphingosine-1-phosphate-1 (S1P1) receptor agonists with exceptional selectivity against S1P2 and S1P3. J. Med. Chem. 48: 6169-73 [PMID:16190743]

97. Liu G, Burns S, Huang G, Boyd K, Proia RL, Flavell RA and Chi H. (2009) The receptor S1P1 overrides regulatory T cell-mediated immune suppression through Akt-mTOR. Nat. Immunol. 10: 769-77 [PMID:19483717]

98. Liu Y, Wada R, Yamashita T, Mi Y, Deng CX, Hobson JP, Rosenfeldt HM, Nava VE, Chae SS and Lee MJ et al.. (2000) Edg-1, the G protein-coupled receptor for sphingosine-1-phosphate, is essential for vascular maturation. J. Clin. Invest. 106: 951-61 [PMID:11032855]

99. Mackle T, Gendy SS, Walsh M, McConn-Walsh R, Costello RW and Walsh MT. (2008) Role of sphingosine 1-phosphate receptor expression in eosinophils of patients with allergic rhinitis, and effect of topical nasal steroid treatment on this receptor expression. J Laryngol Otol 122: 1309-17 [PMID:18808729]

100. MacLennan AJ, Benner SJ, Andringa A, Chaves AH, Rosing JL, Vesey R, Karpman AM, Cronier SA, Lee $\mathrm{N}$ and Erway LC et al.. (2006) The S1P2 sphingosine 1-phosphate receptor is essential for auditory and vestibular function. Hear. Res. 220: 38-48 [PMID:16945494]

101. MacLennan AJ, Browe CS, Gaskin AA, Lado DC and Shaw G. (1994) Cloning and characterization of a putative G-protein coupled receptor potentially involved in development. Mol. Cell. Neurosci. 5: 201-9 [PMID:8087418]

102. MacLennan AJ, Carney PR, Zhu WJ, Chaves AH, Garcia J, Grimes JR, Anderson KJ, Roper SN and Lee N. (2001) An essential role for the H218/AGR16/Edg-5/LP(B2) sphingosine 1-phosphate receptor in neuronal excitability. Eur. J. Neurosci. 14: 203-9 [PMID:11553273]

103. Malek RL, Toman RE, Edsall LC, Wong S, Chiu J, Letterle CA, Van Brocklyn JR, Milstien S, Spiegel S and Lee $\mathrm{NH}$. (2001) Nrg-1 belongs to the endothelial differentiation gene family of $\mathrm{G}$ protein-coupled sphingosine-1-phosphate receptors. J. Biol. Chem. 276: 5692-9 [PMID:11069896]

104. Mandala S, Hajdu R, Bergstrom J, Quackenbush E, Xie J, Milligan J, Thornton R, Shei GJ, Card D and Keohane C et al.. (2002) Alteration of lymphocyte trafficking by sphingosine-1-phosphate receptor agonists. Science 296: 346-9 [PMID:11923495]

105. Martinborough E, Boehm MF, Yeager AR, Tamiya J, Huang L, Brahmachary E, Moorjani M, Timony GA, Brooks JL and Peach R et al.. (2011) Selective sphingosine 1 phosphate receptor modulators and methods of chiral synthesis. Patent number: US20110172202 A1.

106. Matloubian M, Lo CG, Cinamon G, Lesneski MJ, Xu Y, Brinkmann V, Allende ML, Proia RL and Cyster JG. (2004) Lymphocyte egress from thymus and peripheral lymphoid organs is dependent on S1P receptor 1. Nature 427: 355-60 [PMID:14737169]

107. McQuiston T, Luberto C and Del Poeta M. (2011) Role of sphingosine-1-phosphate (S1P) and S1P receptor 2 in the phagocytosis of Cryptococcus neoformans by alveolar macrophages. Microbiology (Reading, Engl.) 157: 1416-27 [PMID:21292747]

108. Means CK, Xiao CY, Li Z, Zhang T, Omens JH, Ishii I, Chun J and Brown JH. (2007) Sphingosine 1phosphate S1P2 and S1P3 receptor-mediated Akt activation protects against in vivo myocardial ischemiareperfusion injury. Am. J. Physiol. Heart Circ. Physiol.292: H2944-51 [PMID:17293497]

109. Mizuno H and Kihara Y. (2020) Druggable Lipid GPCRs: Past, Present, and Prospects. Adv Exp Med Biol 1274: 223-258 [PMID:32894513]

110. Murakami A, Takasugi H, Ohnuma S, Koide Y, Sakurai A, Takeda S, Hasegawa T, Sasamori J, Konno T 
and Hayashi K et al.. (2010) Sphingosine 1-phosphate (S1P) regulates vascular contraction via S1P3 receptor: investigation based on a new S1P3 receptor antagonist. Mol. Pharmacol. 77: 704-13 [PMID:20097776]

111. Nofer JR, van der Giet M, Tölle M, Wolinska I, von Wnuck Lipinski K, Baba HA, Tietge UJ, Gödecke A, Ishii I and Kleuser B et al.. (2004) HDL induces NO-dependent vasorelaxation via the lysophospholipid receptor S1P3. J. Clin. Invest. 113: 569-81 [PMID:14966566]

112. Ogle ME, Olingy CE, Awojoodu AO, Das A, Ortiz RA, Cheung HY and Botchwey EA. (2017) Sphingosine1-Phosphate Receptor-3 Supports Hematopoietic Stem and Progenitor Cell Residence Within the Bone Marrow Niche. Stem Cells 35: 1040-1052 [PMID:28026131]

113. Okamoto H, Takuwa N, Gonda K, Okazaki H, Chang K, Yatomi Y, Shigematsu H and Takuwa Y. (1998) EDG1 is a functional sphingosine-1-phosphate receptor that is linked via a Gi/o to multiple signaling pathways, including phospholipase $\mathrm{C}$ activation, Ca2+ mobilization, Ras-mitogen-activated protein kinase activation, and adenylate cyclase inhibition. J. Biol. Chem. 273: 27104-10 [PMID:9765227]

114. Okamoto H, Takuwa N, Yatomi Y, Gonda K, Shigematsu H and Takuwa Y. (1999) EDG3 is a functional receptor specific for sphingosine 1-phosphate and sphingosylphosphorylcholine with signaling characteristics distinct from EDG1 and AGR16. Biochem. Biophys. Res. Commun. 260: 203-8 [PMID:10381367]

115. Olivera A. (2008) Unraveling the complexities of sphingosine-1-phosphate function: the mast cell model. Prostaglandins Other Lipid Mediat. 86: 1-11 [PMID:18403224]

116. Oo ML, Thangada S, Wu MT, Liu CH, Macdonald TL, Lynch KR, Lin CY and Hla T. (2007) Immunosuppressive and anti-angiogenic sphingosine 1-phosphate receptor-1 agonists induce ubiquitinylation and proteasomal degradation of the receptor. J. Biol. Chem. 282: 9082-9 [PMID:17237497]

117. Osada M, Yatomi Y, Ohmori T, Ikeda H and Ozaki Y. (2002) Enhancement of sphingosine 1-phosphateinduced migration of vascular endothelial cells and smooth muscle cells by an EDG-5 antagonist. Biochem. Biophys. Res. Commun. 299: 483-7 [PMID:12445827]

118. Osinde M, Mullershausen F and Dev KK. (2007) Phosphorylated FTY720 stimulates ERK phosphorylation in astrocytes via S1P receptors. Neuropharmacology 52: 1210-8 [PMID:17379261]

119. Oskeritzian CA, Price MM, Hait NC, Kapitonov D, Falanga YT, Morales JK, Ryan JJ, Milstien S and Spiegel S. (2010) Essential roles of sphingosine-1-phosphate receptor 2 in human mast cell activation, anaphylaxis, and pulmonary edema. J. Exp. Med. 207: 465-74 [PMID:20194630]

120. Pan S, Gray NS, Gao W, Mi Y, Fan Y, Wang X, Tuntland T, Che J, Lefebvre S and Chen Yet al.. (2013) Discovery of BAF312 (Siponimod), a Potent and Selective S1P Receptor Modulator. ACS Med Chem Lett 4: 333-7 [PMID:24900670]

121. Pan S, Mi Y, Pally C, Beerli C, Chen A, Guerini D, Hinterding K, Nuesslein-Hildesheim B, Tuntland T and Lefebvre $S$ et al.. (2006) A monoselective sphingosine-1-phosphate receptor-1 agonist prevents allograft rejection in a stringent rat heart transplantation model. Chem. Biol. 13: 1227-34 [PMID:17114004]

122. Pereira JP, Xu Y and Cyster JG. (2010) A role for S1P and S1P1 in immature-B cell egress from mouse bone marrow. PLoS ONE 5: e9277 [PMID:20174580]

123. Piali L, Birker-Robaczewska M, Lescop C, Froidevaux S, Schmitz N, Morrison K, Kohl C, Rey M, Studer R and Vezzali E et al.. (2017) Cenerimod, a novel selective S1P1receptor modulator with unique signaling properties. Pharmacol Res Perspect 5: [PMID:29226621]

124. Poirier B, Briand V, Kadereit D, Schäfer M, Wohlfart $P$, Philippo MC, Caillaud D, Gouraud L, Grailhe $P$ and Bidouard JP et al.. (2020) A G protein-biased S1P1 agonist, SAR247799, protects endothelial cells without affecting lymphocyte numbers. Sci Signal 13: [PMID:32487716]

125. Price MM, Oskeritzian CA, Milstien S and Spiegel S. (2008) Sphingosine-1-phosphate synthesis and functions in mast cells. Future Lipido/ 3: 665-674 [PMID:19802381]

126. Proia RL and Hla T. (2015) Emerging biology of sphingosine-1-phosphate: its role in pathogenesis and therapy. J. Clin. Invest. 125: 1379-87 [PMID:25831442]

127. Quancard J, Bollbuck B, Janser P, Angst D, Berst F, Buehlmayer P, Streiff M, Beerli C, Brinkmann V and Guerini D et al.. (2012) A potent and selective S1P(1) antagonist with efficacy in experimental autoimmune encephalomyelitis. Chem. Biol. 19: 1142-51 [PMID:22999882]

128. Riganti L, Antonucci F, Gabrielli M, Prada I, Giussani P, Viani P, Valtorta F, Menna E, Matteoli M and Verderio C. (2016) Sphingosine-1-Phosphate (S1P) Impacts Presynaptic Functions by Regulating Synapsin I Localization in the Presynaptic Compartment. J. Neurosci. 36: 4624-34 [PMID:27098703]

129. Sanna MG, Liao J, Jo E, Alfonso C, Ahn MY, Peterson MS, Webb B, Lefebvre S, Chun J and Gray Mt al.. (2004) Sphingosine 1-phosphate (S1P) receptor subtypes S1P1 and S1P3, respectively, regulate lymphocyte recirculation and heart rate. J. Biol. Chem. 279: 13839-48 [PMID:14732717]

130. Sanna MG, Vincent KP, Repetto E, Nguyen N, Brown SJ, Abgaryan L, Riley SW, Leaf NB, Cahalan SM and Kiosses WB et al.. (2016) Bitopic Sphingosine 1-Phosphate Receptor 3 (S1P3) Antagonist Rescue from Complete Heart Block: Pharmacological and Genetic Evidence for Direct S1P3 Regulation of Mouse Cardiac Conduction. Mol. Pharmacol. 89: 176-86 [PMID:26494861]

131. Sanna MG, Wang SK, Gonzalez-Cabrera PJ, Don A, Marsolais D, Matheu MP, Wei SH, Parker I, Jo E and Cheng WC et al.. (2006) Enhancement of capillary leakage and restoration of lymphocyte egress by a chiral S1P1 antagonist in vivo. Nat. Chem. Biol. 2: 434-41 [PMID:16829954]

132. Sassoli C, Pierucci F, Tani A, Frati A, Chellini F, Matteini F, Vestri A, Anderloni G, Nosi D and ZecchiOrlandini S et al.. (2018) Sphingosine 1-Phosphate Receptor 1 Is Required for MMP-2 Function in Bone Marrow Mesenchymal Stromal Cells: Implications for Cytoskeleton Assembly and Proliferation. Stem Cells 
Int 2018: 5034679 [PMID:29713350]

133. Satsu H, Schaeffer MT, Guerrero M, Saldana A, Eberhart C, Hodder P, Cayanan C, Schürer S, Bhhatarai B and Roberts E et al.. (2013) A sphingosine 1-phosphate receptor 2 selective allosteric agonist.Bioorg Med Chem 21: 5373-82 [PMID:23849205]

134. Sawicka E, Zuany-Amorim C, Manlius C, Trifilieff A, Brinkmann V, Kemeny DM and Walker C. (2003) Inhibition of Th1- and Th2-mediated airway inflammation by the sphingosine 1-phosphate receptor agonist FTY720. J. Immunol. 171: 6206-14 [PMID:14634137]

135. Schulze T, Golfier S, Tabeling C, Räbel K, Gräler MH, Witzenrath M and Lipp M. (2011) Sphingosine-1phospate receptor $4\left(\mathrm{~S}_{1} \mathrm{P}_{4}\right)$ deficiency profoundly affects dendritic cell function and $\mathrm{TH} 17$-cell differentiation in a murine model. FASEB J 25: 4024-36 [PMID:21825036]

136. Schwab SR and Cyster JG. (2007) Finding a way out: Iymphocyte egress from lymphoid organs Nat. Immunol. 8: 1295-301 [PMID:18026082]

137. Scott FL, Clemons B, Brooks J, Brahmachary E, Powell R, Dedman H, Desale HG, Timony GA, Martinborough E and Rosen $\mathrm{H}$ et al.. (2016) Ozanimod (RPC1063) is a potent sphingosine-1-phosphate receptor-1 (S1P1) and receptor-5 (S1P5 ) agonist with autoimmune disease-modifying activity. Br. J. Pharmacol. 173: 1778-92 [PMID:26990079]

138. Shimano K, Maeda Y, Kataoka H, Murase M, Mochizuki S, Utsumi H, Oshita K and Sugahara K. (2019) Amiselimod (MT-1303), a novel sphingosine 1-phosphate receptor-1 functional antagonist, inhibits progress of chronic colitis induced by transfer of CD4+CD45RBhigh T cells. PLoS One 14: e0226154 [PMID:31805144]

139. Skoura A, Sanchez T, Claffey K, Mandala SM, Proia RL and Hla T. (2007) Essential role of sphingosine 1phosphate receptor 2 in pathological angiogenesis of the mouse retina. J. Clin. Invest. 117: 2506-16 [PMID:17710232]

140. Sobel K, Monnier L, Menyhart K, Bolinger M, Studer R, Nayler O and Gatfield J. (2015) FTY720 Phosphate Activates Sphingosine-1-Phosphate Receptor 2 and Selectively Couples to Ga12/13/Rho/ROCK to Induce Myofibroblast Contraction. Mol. Pharmacol. 87: 916-27 [PMID:25762025]

141. Song J, Matsuda C, Kai Y, Nishida T, Nakajima K, Mizushima T, Kinoshita M, Yasue T, Sawa Y and Ito T. (2008) A novel sphingosine 1-phosphate receptor agonist, 2-amino-2-propanediol hydrochloride (KRP203), regulates chronic colitis in interleukin-10 gene-deficient mice. J. Pharmacol. Exp. Ther. 324: 276-83 [PMID:17898319]

142. Subei AM and Cohen JA. (2015) Sphingosine 1-phosphate receptor modulators in multiple sclerosis.CNS Drugs 29: 565-75 [PMID:26239599]

143. Sugahara K, Maeda Y, Shimano K, Mogami A, Kataoka H, Ogawa K, Hikida K, Kumagai H, Asayama M and Yamamoto T et al.. (2017) Amiselimod, a novel sphingosine 1-phosphate receptor-1 modulator, has potent therapeutic efficacy for autoimmune diseases, with low bradycardia risk. Br. J. Pharmacol. 174: 1527 [PMID:27714763]

144. Szczepaniak WS, Pitt BR and McVerry BJ. (2010) S1P2 receptor-dependent Rho-kinase activation mediates vasoconstriction in the murine pulmonary circulation induced by sphingosine 1-phosphate. Am. J. Physiol. Lung Cell Mol. Physiol. 299: L137-45 [PMID:20435688]

145. Takabe K, Paugh SW, Milstien S and Spiegel S. (2008) "Inside-out" signaling of sphingosine-1-phosphate: therapeutic targets. Pharmacol. Rev. 60: 181-95 [PMID:18552276]

146. Taylor Meadows KR, Steinberg MW, Clemons B, Stokes ME, Opiteck GJ, Peach R and Scott FL. (2018) Ozanimod (RPC1063), a selective S1PR1 and S1PR5 modulator, reduces chronic inflammation and alleviates kidney pathology in murine systemic lupus erythematosus. PLoS ONE 13: e0193236 [PMID:29608575]

147. Tedford K, Steiner M, Koshutin S, Richter K, Tech L, Eggers Y, Jansing I, Schilling K, Hauser AE and Korthals $\mathrm{M}$ et al.. (2017) The opposing forces of shear flow and sphingosine-1-phosphate control marginal zone B cell shuttling. Nat Commun 8: 2261 [PMID:29273735]

148. Terai K, Soga T, Takahashi M, Kamohara M, Ohno K, Yatsugi S, Okada M and Yamaguchi T. (2003) Edg8 receptors are preferentially expressed in oligodendrocyte lineage cells of the rat CNS. Neuroscience 116: 1053-62 [PMID:12617946]

149. Theilmeier G, Schmidt C, Herrmann J, Keul P, Schäfers M, Herrgott I, Mersmann J, Larmann J, Hermann S and Stypmann J et al.. (2006) High-density lipoproteins and their constituent, sphingosine-1-phosphate, directly protect the heart against ischemia/reperfusion injury in vivo via the S1P3 lysophospholipid receptor. Circulation 114: 1403-9 [PMID:16982942]

150. Urbano M, Guerrero M, Rosen H and Roberts E. (2013) Modulators of the Sphingosine 1-phosphate receptor 1. Bioorg. Med. Chem. Lett. 23: 6377-89 [PMID:24125884]

151. Urbano M, Guerrero M, Velaparthi S, Crisp M, Chase P, Hodder P, Schaeffer MT, Brown S, Rosen H and Roberts E. (2011) Discovery, synthesis and SAR analysis of novel selective small molecule S1P4-R agonists based on a (2Z,5Z)-5-((pyrrol-3-yl)methylene)-3-alkyl-2-(alkylimino)thiazolidin-4-one chemotype. Bioorg. Med. Chem. Lett. 21: 6739-45 [PMID:21982495]

152. Van Brocklyn JR, Gräler MH, Bernhardt G, Hobson JP, Lipp M and Spiegel S. (2000) Sphingosine-1phosphate is a ligand for the G protein-coupled receptor EDG-6. Blood 95: 2624-9 [PMID:10753843]

153. Van Brocklyn JR, Tu Z, Edsall LC, Schmidt RR and Spiegel S. (1999) Sphingosine 1-phosphate-induced cell rounding and neurite retraction are mediated by the $\mathrm{G}$ protein-coupled receptor H218. J. Biol. Chem. 274: 4626-32 [PMID:9988698]

154. Walzer T, Chiossone L, Chaix J, Calver A, Carozzo C, Garrigue-Antar L, Jacques Y, Baratin M, Tomasello E and Vivier E. (2007) Natural killer cell trafficking in vivo requires a dedicated sphingosine 1-phosphate 
receptor. Nat. Immunol. 8: 1337-44 [PMID:17965716]

155. Wang W, Graeler MH and Goetzl EJ. (2004) Physiological sphingosine 1-phosphate requirement for optimal activity of mouse CD4+ regulatory T Cells. FASEB J. 18: 1043-5 [PMID:15084513]

156. Wang W, Graeler MH and Goetzl EJ. (2005) Type 4 sphingosine 1-phosphate G protein-coupled receptor (S1P4) transduces S1P effects on T cell proliferation and cytokine secretion without signaling migration. FASEB J. 19: 1731-3 [PMID:16046470]

157. Weth-Malsch D, Langeslag M, Beroukas D, Zangrandi L, Kastenberger I, Quarta S, Malsch P, Kalpachidou T, Schwarzer C and Proia RL et al.. (2016) Ablation of Sphingosine 1-Phosphate Receptor Subtype 3 Impairs Hippocampal Neuron Excitability In vitro and Spatial Working Memory In vivo. Front Cell Neurosci 10: 258 [PMID:27872583]

158. Windh RT, Lee MJ, Hla T, An S, Barr AJ and Manning DR. (1999) Differential coupling of the sphingosine 1-phosphate receptors Edg-1, Edg-3, and H218/Edg-5 to the G(i), G(q), and G(12) families of heterotrimeric G proteins. J. Biol. Chem. 274: 27351-8 [PMID:10488065]

159. Xu J, Gray F, Henderson A, Hicks K, Yang J, Thompson P and Oliver J. (2014) Safety, pharmacokinetics, pharmacodynamics, and bioavailability of GSK2018682, a sphingosine-1-phosphate receptor modulator, in healthy volunteers. Clin Pharmacol Drug Dev 3: 170-8 [PMID:27128606]

160. Yamamoto R, Okada Y, Hirose J, Koshika T, Kawato Y, Maeda M, Saito R, Hattori K, Harada H and Nagasaka $Y$ et al.. (2014) ASP4058, a novel agonist for sphingosine 1-phosphate receptors 1 and 5, ameliorates rodent experimental autoimmune encephalomyelitis with a favorable safety profile. PLOS ONE 9: e110819 [PMID:25347187]

161. Yang AH, Ishii I and Chun J. (2002) In vivo roles of lysophospholipid receptors revealed by gene targeting studies in mice. Biochim. Biophys. Acta 1582: 197-203 [PMID:12069829]

162. Zhang G, Contos JJ, Weiner JA, Fukushima N and Chun J. (1999) Comparative analysis of three murine G-protein coupled receptors activated by sphingosine-1-phosphate. Gene 227: 89-99 [PMID:9931453] 